\title{
Peramalan Indeks Saham LQ45 pada Masa Pandemi COVID-19 Menggunakan Analisis Intervensi
}

\author{
Sherina Arthariani Zukrianto ${ }^{1, a)}$, Widyanti Rahayu ${ }^{1, b)}$, Dania Siregar ${ }^{1, c)}$ \\ ${ }^{1}$ Program Studi Statistika, Fakultas Matematika dan Ilmu Pengetahuan Alam, Universitas Negeri Jakarta \\ Email: ${ }^{\text {a) }}$ sherinaartha@gmail.com, ${ }^{\text {b) }}$ widyanti.rahayu@gmail.com, ${ }^{\text {c) }}$ dania-siregar@unj.ac.id
}

\begin{abstract}
Intervention analysis is a time series method that affected by an event that causes time series data to fluctuate. Intervention analysis method is aimed to measure how big and long an effect from an intervention on the time series data. There are two variable types of intervention analysis, step function and pulse function. This research aimed to model and to forecasting step function on intervention model towards the LQ45 stock index with a known intervention time. LQ45 time series affected by an intervention, which is COVID-19 pandemic. The procedure on intervention analysis method starts with grouping the data into two groups, the data before intervention and the data during intervention until the last data. The data before intervention was used for ARIMA model. The ARIMA model obtained from the data before the intervention is used as information to carry out an intervention order. The next step is to estimate parameter and check a white noise and also normal distribution assumption. Intervention models that comply with both assumptions can be used for forecasting. The result from LQ45 stock index forecasting is a constant LQ45 stock index on stock index level 883 - 884. The LQ45 stock index forecasting result is on a very good range with $7 \%$ error value.
\end{abstract}

Keywords: Intervention analysis, ARIMA, Time Series, LQ45

\begin{abstract}
Abstrak
Analisis intervensi merupakan metode pemodelan deret waktu yang dipengaruhi oleh suatu peristiwa yang menyebabkan data deret waktu mengalami fluktuatif. Metode analisis intervensi memiliki tujuan untuk mengukur besar dan lamanya efek dari suatu intervensi pada data deret waktu. Terdapat dua jenis variabel analisis intervensi, yaitu fungsi step dan fungsi pulse. Tujuan penelitian ini untuk memodelkan dan meramalkan model intervensi fungsi step pada indeks saham LQ45 dengan waktu intervensi yang diketahui. Deret waktu LQ45 dipengaruhi oleh suatu intervensi, yaitu pandemi COVID-19. Prosedur dalam melakukan metode analisis intervensi diawali dengan mengelompokkan data menjadi dua kelompok, yaitu data sebelum intervensi dan data saat intervensi sampai data terakhir. Data sebelum intervensi digunakan untuk pemodelan ARIMA. Model ARIMA yang didapatkan dari data sebelum terjadinya intervensi digunakan sebagai informasi untuk melakukan identifikasi orde intervensi. Selanjutnya dilakukan estimasi parameter dan pemeriksaan uji asumsi white noise serta uji asumsi berdistribusi normal. Model intervensi yang telah memenuhi kedua asumsi tersebut dapat digunakan untuk peramalan. Peramalan dari indeks saham LQ45 menghasilkan nilai indeks saham LQ45 yang cenderung konstan dan berkisar pada level indeks saham sebesar 883 - 884. Hasil peramalan indeks saham LQ45 sudah sangat baik dengan nilai galat sebesar 7\%.
\end{abstract}

Kata-kata kunci: Analisis intervensi, ARIMA, Data Deret Waktu, LQ45 


\section{PENDAHULUAN}

Pada awal tahun 2020 dunia dikejutkan dengan penyebaran virus corona atau COVID-19. Virus tersebut menyebar dengan sangat cepat di Indonesia. Pandemi ini sangat berdampak pada berbagai aspek kehidupan, salah satunya pada perekonomian global dan pasar modal dunia. Salah satu yang terdampak oleh pandemi COVID-19, yaitu indeks saham LQ45 yang merupakan salah satu indeks pasar modal di Bursa Efek Indonesia (BEI). Indeks saham LQ45 adalah indeks yang mengukur kinerja harga saham dari gabungan 45 perusahaan yang memiliki saham terbaik di pasar modal dengan likuiditas serta kapitalisasi pasar yang besar. Indeks saham LQ45 setidaknya dapat menggambarkan 70\% dari kapitalisasi pasar saham di Indonesia (Bursa Efek Indonesia, 2018).

Saham-saham pada BEI tidak menunjukkan peningkatan dan penurunan yang signifikan sebelum terjadinya pandemi di Indonesia, namun setelah terjadinya pandemi COVID-19 hampir semua harga saham di BEI mengalami penurunan termasuk indeks saham LQ45 (Martini and Djohan, 2021). Dilansir oleh CNBC Indonesia bahwa pada tanggal 9 Maret 2020 indeks saham LQ45 turun 8.26\% menjadi 813.75 yang diakibatkan oleh dampak negatif bertambahnya jumlah korban pandemi COVID19 serta kejatuhan harga minyak dunia karena dihadapkan dengan dampak buruk pandemi COVID-19 (Haryanto, 2020). Situasi ini dapat dikatakan bahwa pandemi COVID-19 merupakan suatu intervensi atau peristiwa di luar kendali yang memengaruhi indeks saham LQ45 sehingga mengalami fluktuasi.

Jual-beli pada pasar modal tidak hanya menguntungkan, namun juga memiliki risiko yang cukup besar, terlebih dengan adanya pengaruh intervensi seperti pandemi. Usaha yang dapat dilakukan, yaitu dengan melakukan peramalan. Peramalan atau forecasting merupakan suatu proses untuk memperkirakan suatu keadaan yang akan terjadi di masa yang akan datang. Salah satu metode yang dapat digunakan untuk melakukan peramalan pada data deret waktu adalah dengan metode ARIMA. Kelebihan yang dimiliki dari metode ARIMA yaitu dapat digunakan untuk semua bentuk pola data serta dapat mencapai asumsi kestasioneran pada varian dan kestasioneran pada rata-rata. Dalam situasi tertentu data deret waktu dapat dipengaruhi oleh variabel lain yang dapat berupa suatu peristiwa atau kondisi khusus yang terjadi di luar kendali. Peristiwa tersebut dapat berupa perubahan kebijakan, krisis, atau faktor eksternal lainnya. Peristiwa tersebut disebut sebagai intervensi (Box et al., 2016). Intervensi dapat memengaruhi asumsi stasioneritas pada rata-rata dan varian data deret waktu (Sari et $a l$, 2016). Peristiwa intervensi tersebut dapat mengakibatkan model ARIMA yang dihasilkan menjadi tidak akurat. Dampak dari intervensi yang terjadi pada data deret waktu dapat dianalisis menggunakan suatu metode yang sesuai, yaitu dengan metode analisis intervensi.

Metode analisis intervensi dibedakan menjadi dua macam intervensi, yang disebut dengan fungsi step yang terjadi dalam periode waktu yang lama dan fungsi pulse yang terjadi hanya pada waktu tertentu. Box dan Tiao pertama kali memperkenalkan model intervensi dalam data deret waktu pada tahun 1975 dengan melakukan penelitian tentang pengaruh pengendalian polusi udara pada tingkat oksidan di Los Angeles (Box et al., 2016). Terdapat beberapa penelitian mengenai metode analisis intervensi, diantaranya yaitu yang dilakukan oleh Jarrett dan Kyper pada tahun 2011 yang menunjukkan bahwa indeks saham China dapat dipengaruhi oleh krisis keuangan global (Jarrett and Kyper, 2011). Selanjutnya terdapat penelitian yang berkaitan dengan peramalan harga saham yang dilakukan oleh Damayanti dan Yosmar tentang peramalan harga saham PT. Garuda Indonesia di masa pandemi COVID-19 yang diakibatkan meningkatnya kasus COVID-19 dengan metode analisis intervensi fungsi step (Damayanti \& Yosmar, 2021). Berdasarkan uraian di atas diduga bahwa analisis intervensi dapat digunakan untuk melakukan peramalan harga saham LQ45 dengan baik pada masa pandemi COVID-19, yang dalam hal ini pandemi COVID-19 adalah intervensinya.

\section{METODOLOGI}

\section{Bahan dan Data}

Data yang digunakan pada penelitian ini menggunakan data historical price dari indeks saham LQ45 pada periode September 2019 sampai dengan November 2020 yang diperoleh dari situs 
https://www.investing.com. Data deret waktu yang digunakan sebanyak 386 pengamatan. Pada penelitian ini variabel intervensi yang digunakan adalah pandemi COVID-19 yang terjadi pada tanggal 9 Maret 2020.

\section{Metode Penelitian}

Langkah-langkah analisis yang dilakukan dalam penelitian ini adalah sebagai berikut:

1. Melakukan eksplorasi data indeks saham LQ45 dengan menggunakan plot data deret waktu.

2. Mengelompokkan data menjadi data sebelum intervensi dan data setelah intervensi terjadi sampai data amatan terakhir. Kelompok kesatu adalah data amatan pertama $\mathrm{T}=1$ hingga data sebelum terjadinya intervensi $\mathrm{T}=131$ periode 2 September 2019 hingga 6 Maret 2020. Kelompok data kedua merupakan data saat terjadinya intervensi $\mathrm{T}=132$ hingga data amatan terakhir $\mathrm{T}=306$, yaitu periode 9 Maret 2020 hingga 30 November 2020 .

3. Melakukan pemodelan data sebelum intervensi dengan membangun model ARIMA.

a. Menganalisis stasioner dalam rata-rata dan varian pada model ARIMA

b. Mengidentifikasi model sebelum intervensi dengan plot ACF dan PACF

c. Melakukan identifikasi model dengan melakukan estimasi parameter model

d. Melakukan uji asumsi residual white noise dan uji asumsi residual berdistribusi normal

e. Menentukan model terbaik

f. Melakukan peramalan dari model ARIMA yang dipilih

4. Membangun model Intervensi

a. Melakukan identifikasi nilai orde (b,s,r) menggunakan grafik respon residual didapatkan dari selisih antara residual ARIMA dengan nilai amatan digabungkan dengan selisih antara hasil peramalan ARIMA dengan data amatan saat intervensi hingga data amatan terakhir. Nilai orde b dapat ditentukan dari waktu mulai terjadinya efek intervensi, orde s yang menyatakan jumlah waktu terjadinya efek intervensi yang memengaruhi data hingga data kembali stabil atau mengalami penurunan, dan nilai orde $r$ menunjukkan pola dari pengaruh intervensi yang terjadi setelah $\mathrm{b}$ dan $\mathrm{s}$.

b. Melakukan estimasi parameter model intervensi

c. Melakukan uji asumsi residual white noise dan uji asumsi residual berdistribusi normal pada model intervensi

d. Pemilihan model intervensi terbaik

5. Melakukan peramalan harga indeks saham LQ45 dengan menggunakan model intervensi dan mengukur keakuratan peramalan.

\section{HASIL DAN PEMBAHASAN}

Intervensi pada penelitian ini terjadi karena kondisi pandemi COVID-19 di Indonesia. Pada tanggal 9 Maret 2020 indeks saham LQ45 turun sebesar 8.26\% yang disebabkan oleh sentimen negatif terhadap bertambahnya jumlah korban akibat pandemi COVID-19 (Haryanto, 2020). Hal itu mengakibatkan dampak negatif pada indeks saham LQ45. 


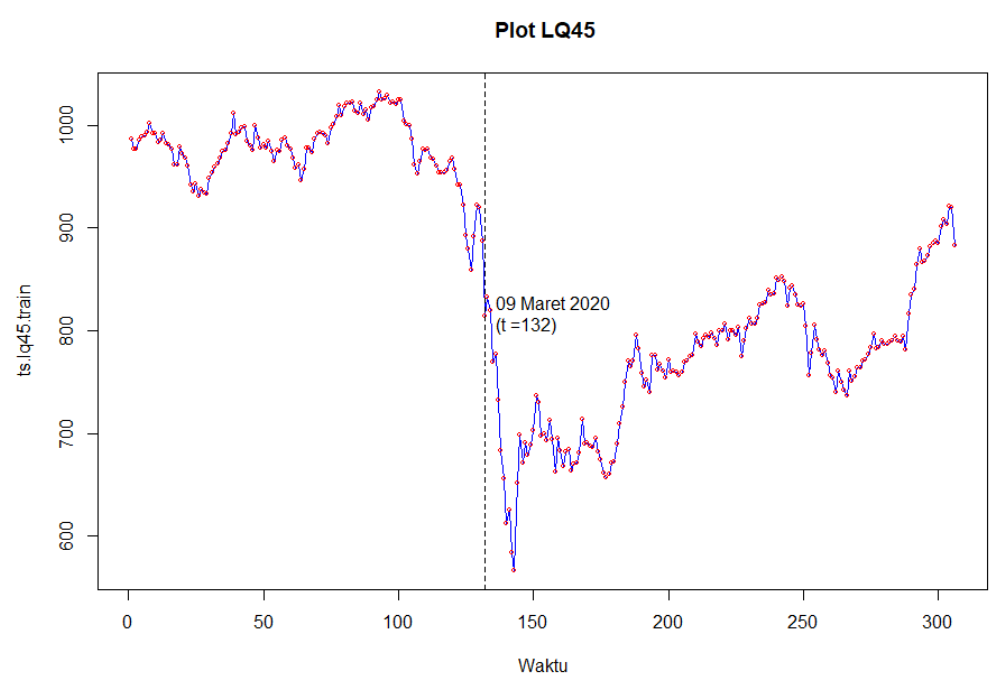

GAMBAR 1. Plot Deret Waktu Data LQ45

GAMBAR 1 menunjukkan plot deret waktu data LQ45 sebelum dan saat adanya intervensi pandemi COVID-19 pada 9 Maret 2020. Pada gambar tersebut terlihat nilai indeks saham LQ45 periode 2 September 2019 sampai dengan 30 November 2020 terbesar terjadi pada tanggal 14 Januari $2020(\mathrm{~T}=93)$ senilai 1032.32 , nilai terendah terjadi pada tanggal 23 Maret $2020(\mathrm{~T}=142)$ senilai 583.41, dan rata-rata senilai 857.06. Fluktuasi yang signifikan terhadap indeks saham LQ45 mulai terjadi setelah satu minggu masuknya pandemi COVID-19 ke Indonesia, yaitu pada tanggal 9 Maret 2020 pada $\mathrm{T}=132$. Pengaruh tersebut mengakibatkan penurunan pada indeks saham LQ45. Langka selanjutnya adalah membangun model ARIMA menggunakan data sebelum intervensi terjadi, yaitu pada waktu $\mathrm{t}<132$ dengan jumlah data $\mathrm{n}=131$.

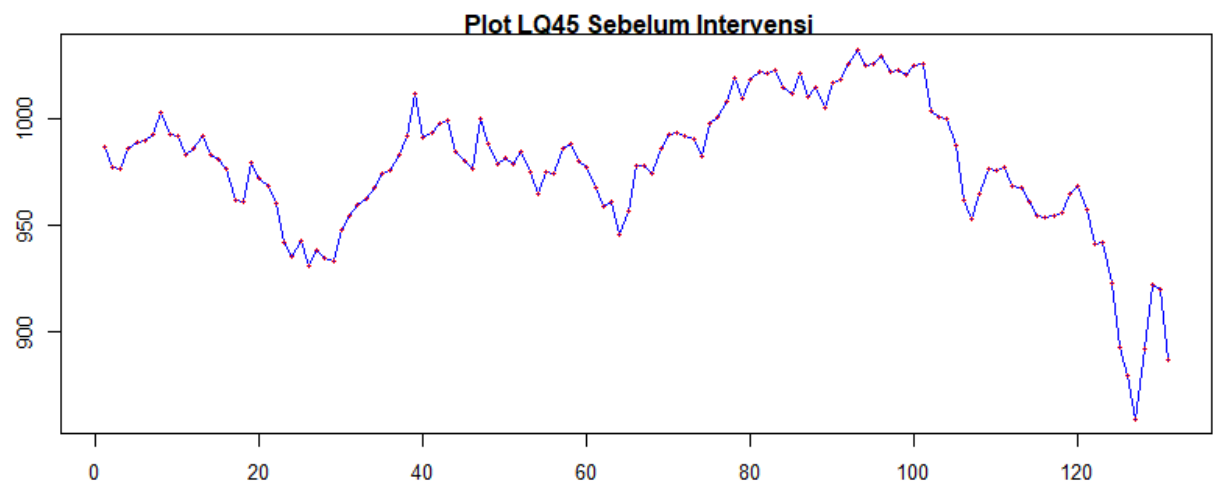

GAMBAR 2. Plot Deret Waktu Data LQ45 Sebelum Intervensi

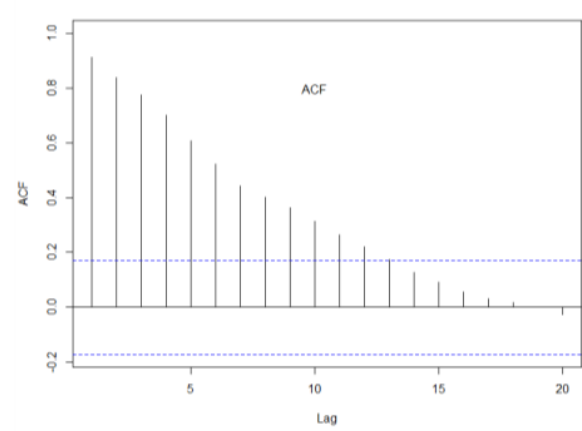

(a)

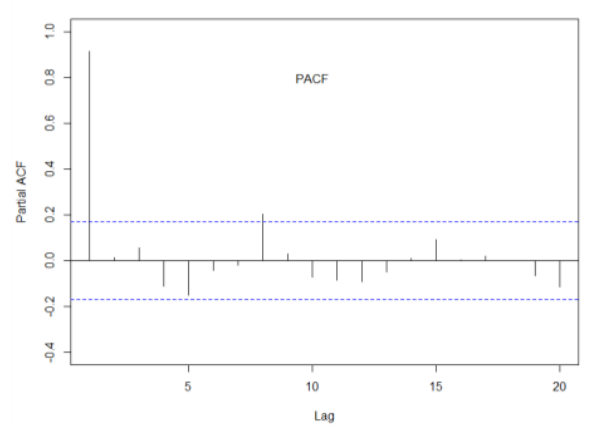

(b)

GAMBAR 3. Plot ACF (a) dan PACF (b) Data LQ45 Sebelum Intervensi 
Dapat dilihat dari GAMBAR 2 bahwa data berfluktuasi naik dan turun yang menandakan data tersebut belum stasioner. Pada GAMBAR 3 plot ACF cenderung menurun perlahan dan tidak berada pada sekitar rata-rata, sehingga dapat diketahui bahwa data belum stasioner dalam rata-rata. Selain dengan melakukan eksplorasi data dengan melihat plot ACF yang turun perlahan, kestasioneran ratarata juga dapat diperiksa dengan uji Augmented Dickey Fuller dan menggunakan uji Levene untuk melihat stasioneritas dalam varian.

TABEL 1. Uji Augmented Dickey Fuller dan Uji Levene

\begin{tabular}{cc}
\hline Pengujian & p-value \\
\hline Uji Augmented Dickey Fuller & 0.9691 \\
Uji Levene & 0.9741 \\
\hline
\end{tabular}

Hasil uji Aumented Dickey Fuller pada TABEL 1 menunjukkan $p$-value sebesar $0.9691>0.05$, sehingga dapat dikatakan bahwa LQ45 belum stasioner dalam rata-rata. Stasioneritas dalam varian dapat diketahui dari hasil uji Levene yang menghasilkan nilai $p$-value sebesar $0.9741>0.05$, sehingga data LQ45 sudah stasioner dalam varian. Berdasarkan hasil dari kedua uji tersebut, perlu dilakukan differencing agar data deret waktu menjadi stasioner dalam rata-rata.

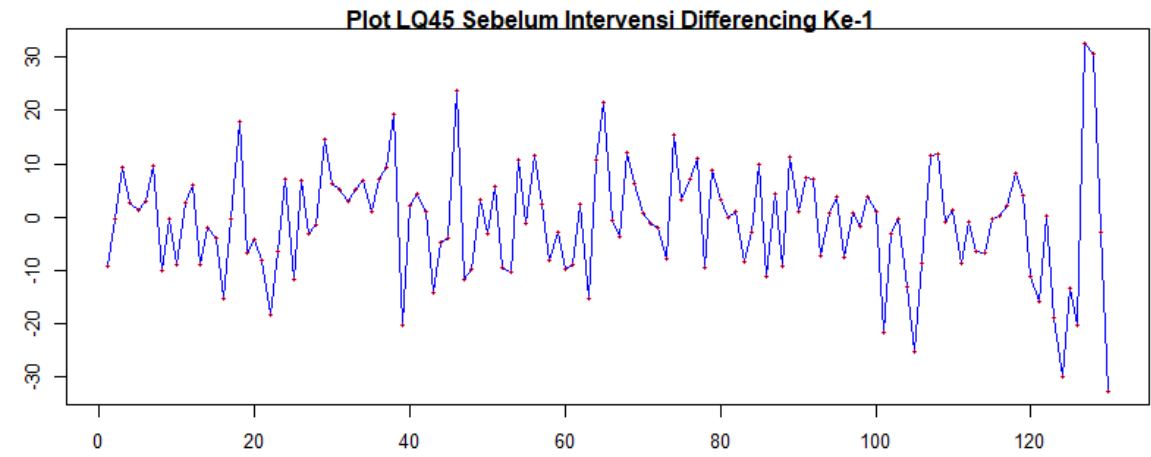

GAMBAR 4. Plot Deret Waktu Data LQ45 Sebelum Intervensi Differencing Ke-1

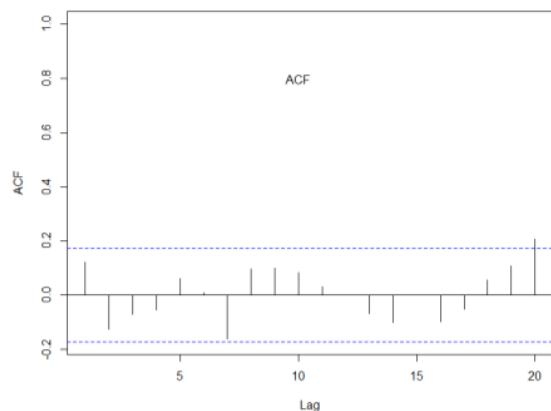

(a)

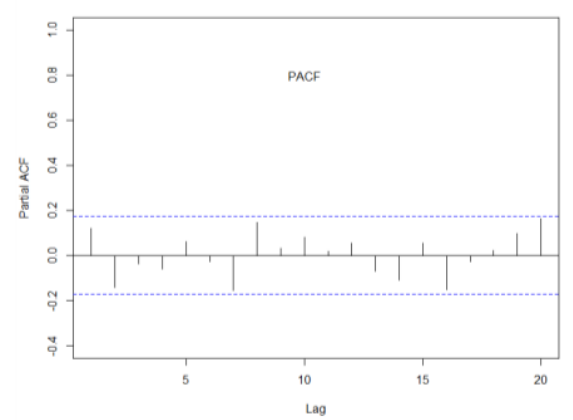

(b)

GAMBAR 5. Plot ACF (a) dan PACF (b) Data LQ45 Sebelum Intervensi Differencing Ke-1

Plot ACF dan PACF sudah stasioner dalam rata-rata setelah dilakukan differencing 1 kali, namun tidak terdapat lag yang signifikan pada plot ACF dan PACF differencing 1 kali. Berdasarkan hal tersebut dilakukan kembali differencing pada data LQ45. Hasil differencing ke-2 pada data LQ45 dapat dilihat pada GAMBAR 6 dan GAMBAR 7. GAMBAR 6 menunjukkan bahwa data sudah stasioner dalam rata-rata. 


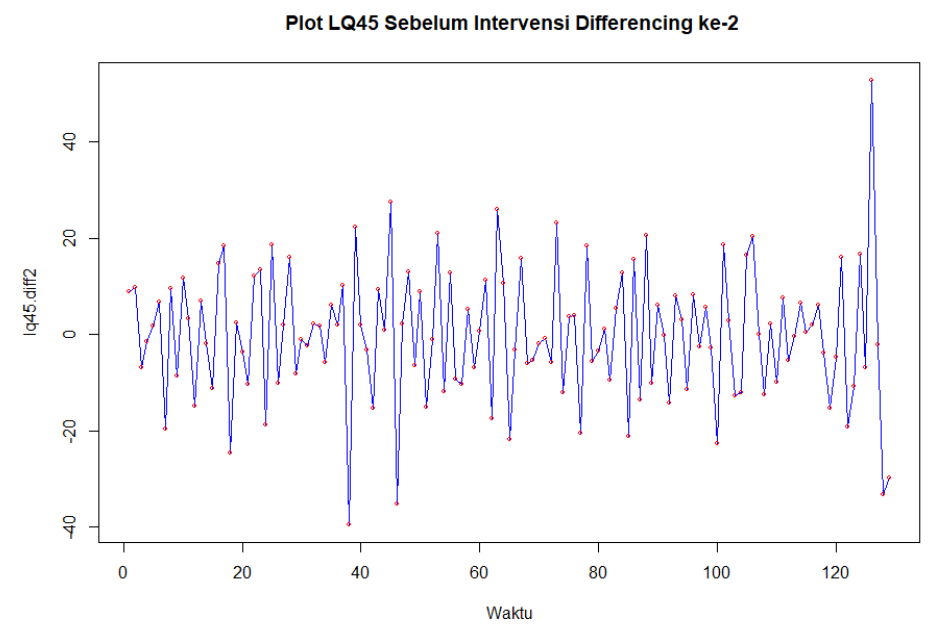

GAMBAR 6. Plot Deret Waktu Data LQ45 Sebelum Intervensi Differencing Ke-2

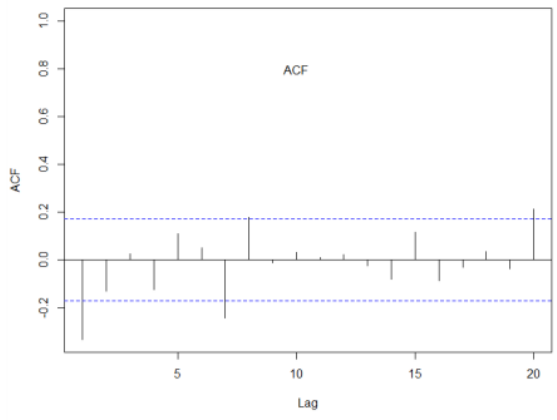

(a)

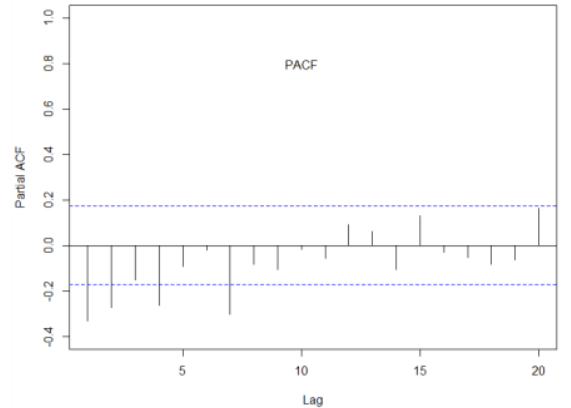

(b)

GAMBAR 7. Plot ACF (a) dan PACF (b) Data LQ45 Sebelum Intervensi Differencing Ke-2

Berdasarkan GAMBAR 7 dapat diketahui bahwa plot ACF cut off di lag ke-1 dan pada plot PACF cut off di lag ke-2 dan ke-4, sehingga didapatkan 3 model sementara, yaitu $\operatorname{IMA}(2,1), \operatorname{ARI}(2,2)$, dan ARI (4,2). Selanjutnya dilakukan estimasi parameter menggunakan metode Maximum Likelihood Estimation dan pemilihan model terbaik dengan melihat nilai MSE, AIC, dan BIC terkecil terhadap ketiga model ARIMA sementara. Didapatkan satu model terbaik dari 3 model sementara tersebut, yaitu model IMA $(2,1)$ karena telah signifikan serta memiliki nilai MSE, AIC, dan BIC yang paling kecil. Setelah itu dilakukan uji asumsi residul white noise dan uji asumsi residual berdistribusi normal.

TABEL 2. Uji Ljung-Box dan Uji Kolmogorov-Smirnov Sebelum Intervensi

\begin{tabular}{cc}
\hline Uji Asumsi Residual & p-value \\
\hline Uji Ljung-Box & 0.169 \\
Uji Kolmogorov-Smirnov & 0.6809 \\
\hline
\end{tabular}

Dari TABEL 2 didapatkan hasil p-value model IMA $(2,1)$ pada perhitungan uji Ljung-Box sebesar 0.169 dan uji Kolmogorov-Smirnov sebesar 0.6809 dengan $\alpha=5 \%$. Hal ini berarti model IMA $(2,1)$ sudah memenuhi asumsi white noise dan berdistribusi normal. Dapat disimpulkan bahwa model IMA $(2,1)$ merupakan model yang layak untuk digunakan pada peramalan.. 


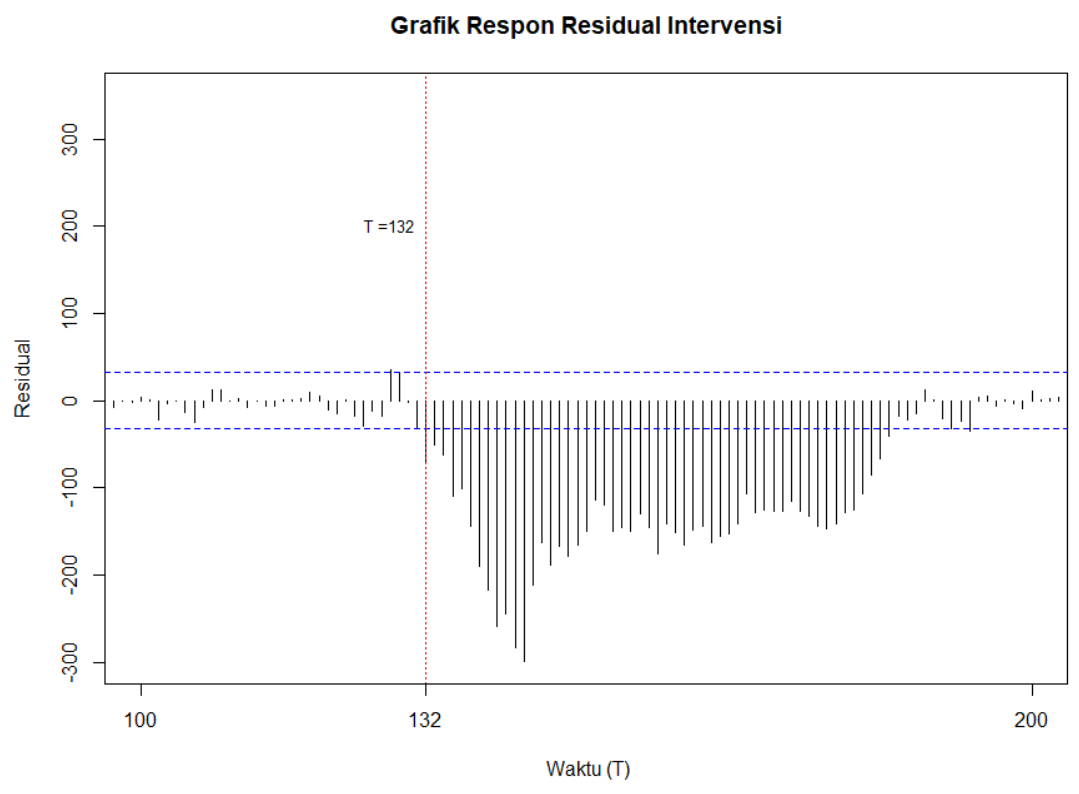

GAMBAR 8. Grafik Respon Residual Intervensi

GAMBAR 8 menunjukkan bahwa lag pada grafik respon residual setelah intervensi terjadi secara bertingkat dan permanent. Hal ini ditunjukkan dengan bentuk lag yang bertingkat dan terjadi dalam waktu yang lama, sehingga mengindikasikan fungsi yang sesuai adalah fungsi step. Grafik respon residual intervensi menunjukkan bahwa lag pertama yang keluar dari batas adalah $\mathrm{T}$, sehingga besar orde $b=0$. Besar lama pengaruh dari intervensi hingga bobot respon mulai turun atau lebih kecil dari lag sebelumnya untuk $\mathrm{s}=0$, karena lama pengaruh intervensi yang dihitung mulai dari lag $\mathrm{T}+1$ tidak lebih signifikan dari periode T. Pola dari diagram respon membentuk pola eksponensial maka besar orde $r=1$. Setelah melakukan identifikasi orde intervensi selanjutnya dilakukan estimasi parameter model intervensi. Hasil uji estimasi parameter $\theta_{1}, \omega_{0}$, dan $\delta_{0}$ dapat dilihat pada TABEL 3.

TABEL 3. Estimasi Parameter Model Intervensi

\begin{tabular}{ccccc}
\hline Parameter & Estimate & Std. Error & Z Value & $\boldsymbol{p}$-value \\
\hline$\theta_{1}$ & -0.9486 & 0.0370 & -25.6091 & $<2.2 \mathrm{e}^{-16}$ \\
$\delta_{0}$ & 0.0140 & 0.0051 & 2.7253 & 0.0064 \\
$\omega_{0}$ & -48.428 & 10.5735 & -4.5801 & $4.646 \mathrm{e}^{-06}$ \\
\hline
\end{tabular}

Berdasarkan TABEL 3 didapatkan nilai estimasi parameter sebesar $\theta_{1}=-0.9486, \omega_{0}=-48.428$, dan $\delta_{0}=0.0140$. Ketiga parameter tersebut memiliki nilai $p$-value $<0.05$, sehingga dikatakan signifikan dan dapat digunakan untuk model intervensi. Hasil estimasi parameter tersebut dapat menghasilkan model intervensi sebagai berikut:

$$
Z_{t}=\frac{\omega_{0}(B)}{\delta_{1}(B)} B^{0} S_{t}^{(132)^{2}}+\frac{\theta_{1}(B)}{(1-B)^{2}} a_{t}
$$

Model intervensi yang baik adalah model yang memenuhi asumsi white noise dan berdistribusi normal. Dilakukan uji Ljung Box untuk menguji apakah model telah memenuhi asumsi white noise. Dalam menguji apakah suatu model memenuhi asumsi normalitas digunakan uji Kolmogorov Smirnov. Hasil dari kedua uji tersebut dapat dilihat pada TABEL 4. 
TABEL 4. Uji Ljung Box dan Uji Kolmogorov-Smirnov Model Intervensi

\begin{tabular}{cc}
\hline Uji Asumsi Residual & p-value \\
\hline Uji Ljung-Box & 0.2269 \\
Uji Kolmogorov-Smirnov & 0.0670
\end{tabular}

Dari TABEL 4 dapat diketahui uji Ljung-Box dan uji Kolmogorov Smirnov menghasilkan $p$-value $>5 \%$. Hal ini menandakan bahwa model intervensi sudah memenuhi asumsi white noise dan berdistribusi normal. Berdasarkan hasil tersebut model intervensi (1) layak digunakan untuk peramalan. Hasil peramalan tersebut dapat dilihat dalam bentuk plot sebagai berikut:

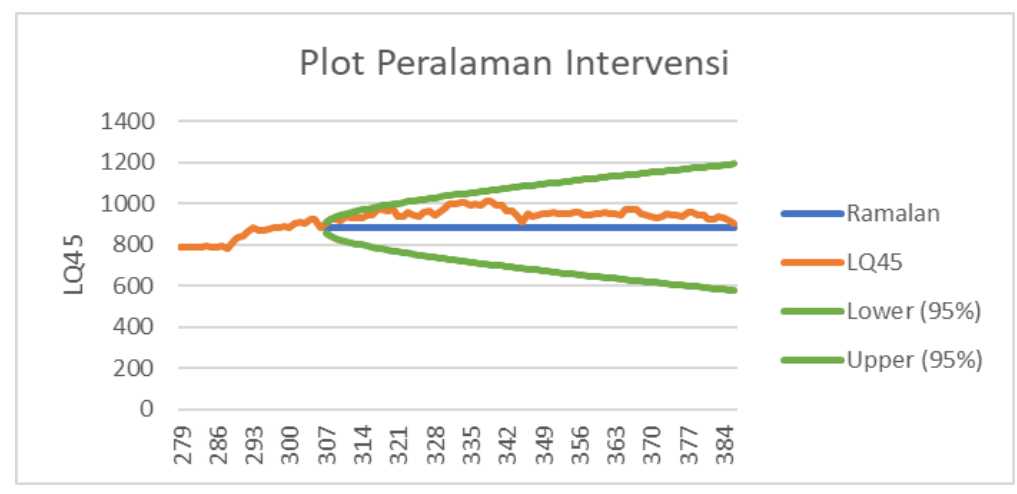

GAMBAR 9. Plot Hasil Peramalan Model Intervensi

GAMBAR 9 menunjukkan bahwa nilai indeks saham LQ45 naik sangat perlahan setiap harinya berkisar pada level 883-884. Berdasarkan hasil peramalan tersebut dapat diketahui indeks saham LQ45 terendah terjadi pada tanggal 1 Desember 2020 sebesar 883.0798 dan terbesar terjadi pada tanggal 31 Maret 2021 sebesar 884.6420. Hasil peramalan dengan model intervensi menghasilkan nilai MAPE < $10 \%$, yaitu $7 \%$ yang berarti hasil peramalan sudah sangat baik.

TABEL 5. Akurasi Peramalan Model Intervensi

\begin{tabular}{cc}
\hline & MAPE \\
\hline Test set & $7.1716 \%$ \\
\hline
\end{tabular}

\section{KESIMPULAN DAN SARAN}

Berdasarkan hasil dan pembahasan tentang analisis intervensi fungsi step terhadap indeks saham LQ45 dengan intervensi pandemi COVID-19 diperoleh kesimpulan, yaitu nilai indeks saham LQ45 periode 2 September 2019 sampai dengan 30 November 2020 dengan intervensi pandemi COVID-19 yang terjadi pada 9 Maret 2020, menghasilkan nilai terbesar terjadi pada tanggal 14 Januari 2020 senilai 1032.32 dan nilai terendah terjadi pada tanggal 23 Maret 2020 senilai 583.41. Rata-rata dari indeks saham LQ45 periode tersebut adalah 857.06. Peramalan dari indeks saham LQ45 dari tanggal 2 September 2019 hingga 30 November 2020 dengan model intervensi untuk tanggal 1 Desember 2020 sampai dengan 31 Maret 2021 menghasilkan nilai indeks saham LQ45 yang cenderung konstan dan berkisar pada level indeks saham 883-884. Hasil peramalan indeks saham LQ45 sudah sangat baik dengan nilai galat sebesar $7 \%$.

Saran yang dapat diberikan, yaitu pada penelitian ini hanya berdasarkan metode ARIMA dan hanya terdapat satu faktor intervensi dengan fungsi step. Pada penelitian selanjutnya dapat melakukan penelitian dengan menggunakan analisis intervensi multi-input dengan lebih satu faktor intervensi agar mendapatkan informasi yang lebih akurat. 


\section{REFERENSI}

Box, G. E. P, Jenkins, G. M, Reinsel, G. C, \& Ljung, G. M 2016, 'Time Series Analysis: Forecasting and Control: Fifth Edition', New Jersey: John Wiley \& Sons, Inc.

Bursa Efek Indonesia 2018, 'LQ45 Index Methodology By IDX', dilihat 12 Februari 2021, www.idx.co.id.

Haryanto 2020, 'Panik Corona \& Perang Minyak, 15 Saham LQ45 Drop 10\%', dilihat 11 Juli 2021, https://www.cnbcindonesia.com/market/20200309165624-17-143527/panik-corona-perangminyak-15-saham-lq45-drop-10.

Jarrett, J. E \& Kyper, E 2011, 'ARIMA Modeling with Intervention to Forecast and Analyze Chinese Stock Prices', International Journal of Engineering Business Management, vol. 3(3), hh. 53-58.

Martini, M \& Djohan, H. A 2021, 'Analisis Kinerja Saham LQ45 Sebelum dan Selama Pandemi Coronavirus Disease (Covid-19) di Indonesia', Jurnal Interprof, vol. 4(2), hh. 148-155.

Sari, R. N, Mariani, S, \& Hendikawati, P 2016, 'Analisis Intervensi Fungsi Step Pada Harga Saham (Studi Kasus Saham PT Fast Food Indonesia Tbk)’, vol. 5(2). 